\title{
Interactive effects of oyster and seaweed on seawater dissolved inorganic carbon systems: implications for integrated multi-trophic aquaculture
}

\author{
Tingting Han ${ }^{1}$, Rongjun Shi ${ }^{1,2}$, Zhanhui Qi ${ }^{1, *}$, Honghui Huang ${ }^{1}$, Qingyang Liang ${ }^{1}$, \\ Huaxue Liu ${ }^{1}$ \\ ${ }^{1}$ Guangdong Provincial Key Laboratory of Fishery Ecology Environment and Key Laboratory of South China Sea \\ Fishery Resources Exploitation and Utilization, Ministry of Agriculture, South China Sea Fisheries Research Institute, \\ Chinese Academy of Fishery Sciences, Guangzhou 510300, PR China \\ ${ }^{2}$ Guangdong Provincial Key Laboratory of Applied Marine Biology, South China Sea Institute of Oceanology, \\ Chinese Academy of Sciences, Guangzhou 510301, PR China
}

\begin{abstract}
We examined the separate effect of Portuguese oyster Crassostrea angulata and the interactive effects of oyster and red seaweed Gracilaria lemaneiformis on seawater dissolved inorganic carbon (DIC) systems and the air-sea $\mathrm{CO}_{2}$ flux $\left(F_{\mathrm{CO} 2}\right)$ in Daya Bay, southern China. Respiration and calcification rates of oysters were measured and the effects of oyster aquaculture on marine DIC systems were evaluated. The interactive effects on seawater DIC and air-sea $F_{\mathrm{CO} 2}$ were examined using mesocosms containing oyster and seaweed assemblages. Results showed populations of $C$. angulata cultured in Daya Bay sequestered ca. $258 \mathrm{~g} \mathrm{C} \mathrm{m}^{-2} \mathrm{yr}^{-1}$ for shell formation, whereas the $\mathrm{CO}_{2}$ released due to respiration and calcification was 349 and $153 \mathrm{~g} \mathrm{C} \mathrm{m}^{-2} \mathrm{yr}^{-1}$, respectively. This indicates that oyster cultivation in Daya Bay is a $\mathrm{CO}_{2}$ generator, favoring the escape of $\mathrm{CO}_{2}$ into the atmosphere. $\mathrm{DIC}, \mathrm{HCO}_{3}{ }^{-}$and $\mathrm{CO}_{2}$ concentrations and the partial pressure of $\mathrm{CO}_{2}$ in oyster-seaweed co-cultured mesocosms were significantly lower than the oyster monoculture mesocosm. These results indicated that $G$. lemaneiformis effectively absorbs the $\mathrm{CO}_{2}$ released by oysters. The negative values of air-sea $F_{\mathrm{CO} 2}$ in the co-culture groups represent a $\mathrm{CO}_{2}$ sink from the atmosphere to the sea. These results demonstrated that there could be an interspecies mutual benefit for both C. angulata and G. lemaneiformis in the integrated culture system. Considering that photosynthesis of seaweed is carbon limited, we suggest that the 2 species are co-cultured at a ratio of ca. 4:1 (based on fresh weight) for efficient utilization of DIC in seawater by $G$. lemaneiformis, and further to increase the ocean $\mathrm{CO}_{2}$ sink.
\end{abstract}

KEY WORDS: Crassostrea angulata - Gracilaria lemaneiformis · Daya Bay · Dissolved inorganic carbon $\cdot$ Integrated multi-trophic aquaculture $\cdot \mathrm{IMTA} \cdot$ Air-sea $\mathrm{CO}_{2}$ flux

\section{INTRODUCTION}

Calcification of aquatic animals such as shellfish (e.g. oyster, scallop, and clam) is also a source of $\mathrm{CO}_{2}$ (Chauvaud et al. 2003, Martin et al. 2006, Mistri \& Munari 2013, Munari et al. 2013, Jiang et al. 2014). Shellfish utilize carbon in 2 ways. First, they consume organic carbon to sustain their growth and meta-

${ }^{*}$ Corresponding author: qizhanhui@scsfri.ac.cn bolism, following the reaction $\mathrm{CH}_{2} \mathrm{O}+\mathrm{O}_{2} \rightarrow \mathrm{CO}_{2}+$ $\mathrm{H}_{2} \mathrm{O}$. Second, they use $\mathrm{HCO}_{3}{ }^{-}$from seawater to generate $\mathrm{CaCO}_{3}$ shells, based on the reaction $\mathrm{Ca}^{2+}+$ $2 \mathrm{HCO}_{3}^{-} \leftrightarrow \mathrm{CaCO}_{3}+\mathrm{CO}_{2}+\mathrm{H}_{2} \mathrm{O}$. These 2 processes both lead to net $\mathrm{CO}_{2}$ production in ocean waters. Second, shellfish secrete calcium carbonate $\left(\mathrm{CaCO}_{3}\right)$ to form their skeletal material. This process acts as a marine biological pump by removing $\mathrm{CO}_{2}$ from circu-

(C) The authors 2017. Open Access under Creative Commons by Attribution Licence. Use, distribution and reproduction are unrestricted. Authors and original publication must be credited. 
lation and storing carbon in the ocean (Lerman \& Mackenzie 2005). In fact, the ratio of released $\mathrm{CO}_{2}$ /precipitated $\mathrm{CaCO}_{3}$ is largely dependent on the buffering capacity of the surrounding seawater, such that in some marine ecosystems, the ratio could be ca. 0.6 (Frankignoulle et al. 1995). It is reasonable that the buffering capacity of seawater might vary significantly among different waters with variations in $\mathrm{pH}$, alkalinity, salinity, and temperature (Millero 1995, Lerman \& Mackenzie 2005, Dickson 2010, Mackenzie \& Andersson 2013)

Seaweeds (e.g. Saccharina, Gracilaria) are intricately involved as primary producers in coastal ecosystems. They assimilate inorganic carbon either via diffusion (for $\mathrm{CO}_{2}$ ), or active uptake of $\mathrm{HCO}_{3}{ }^{-}$using carbon-concentration mechanisms. During photosynthesis, these mechanisms result in an increase in seawater $\mathrm{pH}$ and a drop in seawater $\mathrm{CO}_{2}$ partial pressure $\left(p \mathrm{CO}_{2}\right)$ (Han et al. 2013). Therefore, seaweed could induce a significant shift in seawater dissolved inorganic carbon (DIC) systems according to the following formula: $\mathrm{CO}_{2}+\mathrm{H}_{2} \mathrm{O} \leftrightarrow \mathrm{H}_{2} \mathrm{CO}_{3} \leftrightarrow \mathrm{H}^{+}+$ $\mathrm{HCO}_{3}{ }^{-} \leftrightarrow 2 \mathrm{H}^{+}+\mathrm{CO}_{3}{ }^{2-}$. Therefore, seaweed may exert a significant impact on the DIC buffering capacity of seawater.

As mentioned above, both shellfish and seaweed can change the seawater DIC system and the buffering capacity. One implication is a complex interspecies interaction between shellfish and seaweed in co-cultured systems. For example, $\mathrm{CO}_{2}$ or $\mathrm{HCO}_{3}{ }^{-}$can become a major limiting factor affecting the photosynthetic rates and aquaculture production of seaweed, particularly when they are grown under conditions of high biomass densities and reduced seawater motion (Zou et al. 2004). Likewise, the alteration in DIC speciation can cause responses in calcifying organisms (e.g. oyster), thereby potentially affecting their growth and physiological functions (Ho \& Carpenter 2017, Scanes et al. 2017). Thus, the interaction between shellfish and seaweed and their combined effect on DIC partitioning and cycling still needs to be investigated using an ecosystem approach. Similarly, few studies have been conducted to elucidate the influence of integrated aquaculture of shellfish and seaweed on variations in DIC systems, as well as the air-sea $\mathrm{CO}_{2}$ flux. Furthermore, the optimum culture ratio in co-culture systems for obtaining the largest $\mathrm{CO}_{2}$ sink is not known.

Shellfish and seaweed mariculture in the coastal waters of China has been growing rapidly over the past 3 decades; they are by far the largest and most well-known aquaculture industries in the world, with an annual production of ca. $13.6 \times 10^{6} \mathrm{t}$ and $2.1 \times$
$10^{6} \mathrm{t}$, accounting for ca. $72.4 \%$ and $11.1 \%$ of the total mariculture production in China, respectively (China Bureau of Fisheries 2016). In most coastal waters, shellfish and seaweed are co-cultured, using suspended longlines as the main cultivation method. In fact, they usually dominate an entire bay, such as in Sanggou Bay (Fang et al. 2016) and in Daya Bay (Yu et al. 2014) where this study was conducted.

In the present study, we conducted an in situ mesocosm experiment to measure the calcification and respiration rates of the Portuguese oyster Crassostrea angulata to evaluate its effect on marine DIC systems. In addition, the role of the red seaweed Gracilaria lemaneiformis was assayed for elimination of $\mathrm{CO}_{2}$ in seawater. Subsequently, we investigated the impact of co-culture interactions on DIC systems and the air-sea $\mathrm{CO}_{2}$ flux using different ratios. The results from this study will be useful in evaluating the effects of large-scale coastal aquaculture of oysters and seaweed on the marine $\mathrm{CO}_{2}$ budget with the hope of finding methods of carbon removal from coastal waters.

\section{MATERIALS AND METHODS}

\section{Study site}

Daya Bay, located in Guangdong Province, southern China, is a $600 \mathrm{~km}^{2}$ semi-enclosed embayment in the northeast South China Sea (Fig. 1). The average water depth is $10 \mathrm{~m}$ (range: $6-20 \mathrm{~m}$ ). The annual mean air temperature is $22^{\circ} \mathrm{C}$. The minimum sea surface temperature occurs in winter $\left(15^{\circ} \mathrm{C}\right)$ and the maximum in summer and fall $\left(30^{\circ} \mathrm{C}\right)$. The bay is one of the most intensive culture areas in China. The Portuguese oyster Crassostrea angulata is the main cultured bivalve species. Suspension aquaculture of $C$. angulata has been practiced for over 3 decades, with an estimated standing stock of $6.6 \times 10^{4} \mathrm{t}$ in 2016 . The seaweed Gracilaria lemaneiformis is another important cultured species, with a production of ca. $27 \times 10^{4} \mathrm{t}$ in China in 2015 (China Bureau of Fisheries 2016).

\section{Estimation of calcification and respiration rate of C. angulata}

Experimental C. angulata were collected from Daya Bay in April 2016 and taken to the laboratory in a temperature-controlled case within $1 \mathrm{~h}$. After arrival, animals were disinfected, and any visible fouling organisms on shell surfaces were cleaned by 


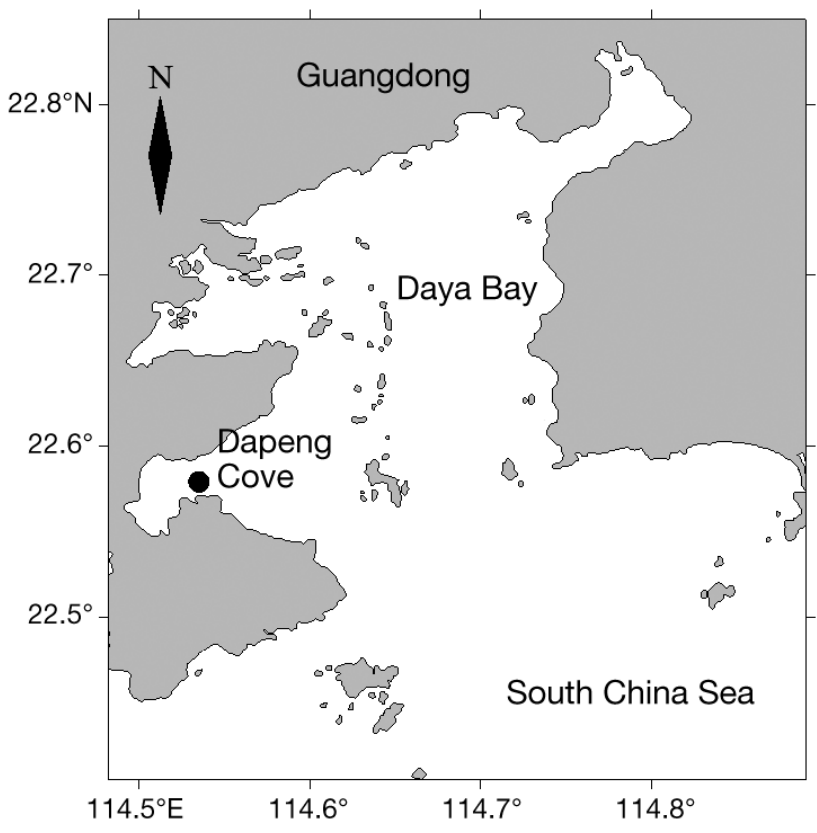

Fig. 1. Location of the study area (๑) in Daya Bay

washing with filtered seawater. Approximately 30 oysters of similar sizes (7-8 $\mathrm{cm}$ shell height) were acclimatized to laboratory conditions for $1 \mathrm{wk}$ in a 501 tank with aerated seawater. During acclimation, seawater was changed once per day and oysters were fed daily with $2 \times 10^{4} \mathrm{cell} \mathrm{ml}^{-1}$ Chaetoceros sp. at 08:00 h. During the trial, temperature $(T)$, salinity $(S)$, and $\mathrm{pH}$ were $22 \pm 1^{\circ} \mathrm{C}, 30.8 \pm 0.1$, and $8.03 \pm 0.02$, respectively.

At the end of the acclimatization period, the oysters were placed in closed 201 transparent polyethylene plastic mesocosms filled with seawater. The mesocosms were hung from a suspended longline so that the experimental oysters were at a depth of ca. $2 \mathrm{~m}$, corresponding to the routine culture depth for oysters. A factorial design was used to test the effects of 3 stocking densities: i.e. low, medium, and high (ca. 1, 5, and $10 \mathrm{~g}$ (fresh weight, FW) oyster $\mathrm{l}^{-1}$, respectively) on water $\mathrm{pH}$, dissolved oxygen (DO), total alkalinity (TA), DIC, and carbonate ion $\left(\mathrm{CO}_{3}{ }^{2-}\right)$ concentrations. Water samples were taken at 0 and $4 \mathrm{~h}$. $T$ and $S$ were measured using a multi-parameter water quality meter (YSI Professional Plus 6600, Yellow Springs Instrument Company). $\mathrm{pH}$ was measured using a $\mathrm{pH}$ meter (Thermo Scientific Orion 320P-01, Thermo Electron Corporation) calibrated on the US National Bureau of Standards scale. The precision of $\mathrm{pH}$ measurements was $\pm 0.01 \mathrm{pH}$ units. Oxygen concentrations were determined by the Winkler method (Strickland \& Parson 1972). TA was measured using an 848 Titrino plus automatic titrator (Metrohm) on
$100 \mathrm{ml} \mathrm{GF} / \mathrm{F}$ filtered samples. The accuracy of measurements was $\pm 2 \mu_{\mathrm{mol}}{ }^{-1}$. DIC and $\mathrm{CO}_{3}{ }^{2-}$ concentrations were computed from $T, S, \mathrm{pH}$, and TA using the $\mathrm{CO}_{2} \_$SYS_XLS calculation program (Pierrot et al. 2006). The dissociation constants for carbonic acid $\left(K_{1}, K_{2}\right)$ were from Mehrbach et al. (1973) as refitted by Dickson \& Millero (1987), the dissociation constant for bisulfate ion $\left(K_{\mathrm{HSO}}\right)$ was obtained from Dickson (1990), and the dissociation constant for boric acid $\left(K_{\mathrm{B}}\right)$ was from Uppstrom (1974).

$\mathrm{CO}_{2}$ respiratory rate $\left(R_{i} \mu \mathrm{mol} \mathrm{FW} \mathrm{g}^{-1} \mathrm{~h}^{-1}\right)$ can be expressed as follows:

$$
\begin{gathered}
\Delta \mathrm{DIC}=\mathrm{DIC}_{\mathrm{f}}-\mathrm{DIC}_{\mathrm{i}} \\
R=\frac{\left(2 \Delta \mathrm{DIC}+\mathrm{TA}_{\mathrm{i}}-\mathrm{TA}_{\mathrm{f}}\right) \times V}{2 \times t \times M}
\end{gathered}
$$

where $\triangle \mathrm{DIC}$ is the net change in DIC concentration $\left(\mu \mathrm{mol} \mathrm{l^{-1 }}\right.$ ), which was caused by the interaction between calcification and respiration. $\mathrm{DIC}_{\mathrm{i}}$ and $\mathrm{DIC}_{\mathrm{f}}$ were the initial and final DIC concentration $(\mu \mathrm{mol}$ $\left.\mathrm{l}^{-1}\right)$, respectively. $V$ is the incubation chamber volume (l), $t$ is the experimental time (h), and $M$ is the fresh weight of experimental oyster $(\mathrm{g})$. $\mathrm{TA}_{\mathrm{i}}$ and $\mathrm{TA}_{\mathrm{f}}$ were the initial and final TA concentration $\left(\mu \mathrm{mol} \mathrm{l}^{-1}\right)$, respectively.

For $\mathrm{CaCO}_{3}$ production, 30 oysters were sampled, and the dry weight (DW) of oyster shell was determined by drying at $80^{\circ} \mathrm{C}$ till constant weight $( \pm 0.01 \mathrm{~g})$. Bivalve shells largely consist $(95 \%)$ of $\mathrm{CaCO}_{3}$, and the remaining $5 \%$ are made up by magnesium, $\beta$-chitin, and various glycoproteins (Goulletquer \& Wolowicz 1989). Shell DWs were corrected accordingly. The calcimass $\left(\mathrm{g} \mathrm{CaCO}_{3} \mathrm{~m}^{-2}\right)$ was estimated by the shell DWs per $\mathrm{m}^{2}$ and its $\mathrm{CaCO}_{3}$ content. Dry tissue weight was calculated for each individual using the ash-free dry weight (AFDW) method: oyster soft tissue was dried at $80^{\circ} \mathrm{C}(72 \mathrm{~h})$ and then ashed at $500^{\circ} \mathrm{C}(4 \mathrm{~h})$, with tissue weight computed as the difference between the 2 weights.

The $\mathrm{CO}_{2}$ released from $C$. angulata respiration was estimated using: (1) the relation established by Schwinghamer et al. (1986): $\log _{10} R=0.367+$ $0.993 \log _{10} P$, where $P$ and $R$ are production and respiration ( $\mathrm{kcal} \mathrm{m}^{-2} \mathrm{yr}^{-1}$ ), respectively; (2) the $22.79 \mathrm{~J}$ $\mathrm{mg} \mathrm{AFDW}^{-1}$ conversion factor for bivalve energetic content (Rumohr et al. 1987); (3) the conversion $1 \mathrm{~J}=$ $0.239 \mathrm{cal}$ (Peters 1983); and (4) the conversion $1 \mathrm{~g} \mathrm{C}=$ $11.4 \mathrm{kcal}$ (Chauvaud et al. 2003).

The monthly ratio of $\mathrm{CO}_{2}$ released to $\mathrm{CaCO}_{3}$ precipitated $(\Psi)$ was estimated as a function of the water temperature, measured with a YSI meter. $\mathrm{CO}_{2}$ fluxes due to calcification were calculated using a $\Psi$ value 
estimated by computing the temperature according to: $\Psi=0.8-8.3 \times 10^{-3} T$, where $T$ is the water temperature $\left({ }^{\circ} \mathrm{C}\right.$ ), and assuming $p \mathrm{CO}_{2}=350$ patm (Fankignoulle et al. 1994).

\section{Deployment of in situ mesocosm experiment}

The in situ mesocosm experiment was carried out from 20 to 22 April 2016 in Daya Bay $\left(22^{\circ} 34^{\prime} \mathrm{N}\right.$, $\left.114^{\circ} 32^{\prime} \mathrm{E}\right)$ (Fig. 1). The cylindrical mesocosms (1 m diameter $\times 1.5 \mathrm{~m}$ height) were made from transparent polyethylene plastic and were hung on suspended longlines with the top ca. $2.0 \mathrm{~m}$ below the water surface. Fifteen cylindrical mesocosms (450 l) were deployed over $24 \mathrm{~h}$ periods and consisted of 5 treatments each with 3 replicates (Table 1 ). One treatment with only seawater served as the control (C), the second treatment contained only oysters (oyster only, O), and the other 3 treatments were coculture systems, with 3 oyster:seaweed ratios, i.e. 8:1, 4:1, and 2:1 (based on FW of oyster and seaweed, referred to as OS_8:1, OS_4:1 and OS_2:1, respectively). After filling with natural seawater, the mouths of the mesocosms were tied using ropes. A pipe was placed in the tied site and maintained for $24 \mathrm{~h}$ to keep DIC concentration in equilibrium with air due to water mixing with air. Oysters and seaweed were coiled into $100-\mathrm{cm}$-long ropes and placed in the mesocosms. The ropes were suspended using thin ropes and tied to the mouth of the mesocosm, such that the seaweed thalli were positioned vertically around the oysters. The mesocosms were immobilized using a set of ropes connected top-side to a float and submerged under the water surface.

The experiment began at 10:00 $\mathrm{h}$ and lasted for $24 \mathrm{~h}$. Water $T, S, \mathrm{DO}, \mathrm{pH}$, and TA were measured at the beginning and end of the experiment. Parameters for the seawater DIC system and aqueous $p \mathrm{CO}_{2}$ were calculated by the CO2_SYS_XLS calculation program (Pierrot et al. 2006).

The sea-air $\mathrm{CO}_{2}$ fluxes $\left(F_{\mathrm{CO} 2}\right)$ were calculated based on the following equation: $F_{\mathrm{CO} 2}=k \times \alpha \times$ $\Delta p \mathrm{CO}_{2}$, where $k\left(\mathrm{~cm} \mathrm{~h}^{-1}\right)$ is the gas exchange coefficient of $\mathrm{CO}_{2}$. We computed $k$ using the parameterization given by Wanninkhof \& McGillis (1999) that uses short-term winds $k=0.0283 u_{10}{ }^{3}(S c / 660)^{-1 / 2} \cdot u_{10}$ stands for the wind speed at a $10 \mathrm{~m}$ height from the water surface level $\left(\mathrm{m} \mathrm{s}^{-1}\right)$ and $S C$ is the Schmidt number calculated according to the relationship proposed by Wanninkhof (1992). $\alpha\left(\mathrm{mol} \mathrm{kg}^{-1} \mathrm{~atm}^{-1}\right)$ is the solubility coefficient of $\mathrm{CO}_{2}$ calculated after Weiss (1974). $\Delta p \mathrm{CO}_{2}$ is the $p \mathrm{CO}_{2}$ difference between
Table 1. Overview of the co-culture systems in the 5 treatments, with oysters and seaweed retained in mesocosms ( $g$ fresh weight per mesocosm, mean $\pm \mathrm{SD}$ )

\begin{tabular}{|lcc|}
\hline Treatment (abbreviation) & Oyster & Seaweed \\
\hline Control (C) & - & - \\
Oyster (O) & $4402 \pm 141$ & - \\
Oyster:seaweed 8:1 (OS_8:1) & $4418 \pm 126$ & $583 \pm 27$ \\
Oyster:seaweed 4:1 (OS_4:1) & $4750 \pm 102$ & $1103 \pm 68$ \\
Oyster:seaweed 2:1 (OS_2:1) & $4631 \pm 150$ & $2210 \pm 115$ \\
\hline
\end{tabular}

surface seawater and the atmosphere. In this study, the value of atmospheric $p \mathrm{CO}_{2}$ was downloaded from www.cmdl.noaa.gov (National Oceanographic and Atmospheric Administration, NOAA, Climate and Meteorological Diagnostics Laboratory) and corrected for water vapor pressure (Takahashi et al. 2002). Positive magnitudes of $F_{\mathrm{CO} 2}$ indicate a flux from water to air and vice versa.

The net oxygen production rate by G. lemaneiformis in co-culture systems was determined based on the DO concentrations in experimental mesocosms, as:

Net oxygen production rate $\left(\mu \mathrm{mol} \mathrm{O}_{2} \mathrm{~g}^{-1} \mathrm{FW} \mathrm{h}^{-1}\right)$

$$
=\left(C_{\mathrm{os}}-C_{\mathrm{o}}\right) \times V / \mathrm{FW} / \mathrm{t}_{\text {, }}
$$

where $C_{\mathrm{os}}$ and $C_{\mathrm{o}}$ are the DO concentrations ( $\mu \mathrm{mol}$ $\mathrm{l}^{-1}$ ) of oyster-seaweed co-culture mesocosms and oyster-only mesocosm, respectively, at the end of the experiment. $V$ is the volume of mesocosms (1), FW is the fresh weight of $G$. lemaneiformis $(\mathrm{g})$, and $t$ is the duration of the experiment (h).

\section{Statistical analysis}

Data were analyzed by 1-way ANOVA. All data were graphically assessed for normality and homogeneity of residuals (Faraway 2002). When overall differences were significant at the 0.05 level, Tukey's HSD multiple range test was used to compare the mean values of individual groups. Data are reported as means $\pm \mathrm{SE}(\mathrm{n}=3)$. All statistical tests were performed using SPSS 17.0 for Windows.

\section{RESULTS}

\section{Calcification and respiration rates of Crassostrea angulata}

As shown in Fig. 2, after a $4 \mathrm{~h}$ incubation, the seawater $\mathrm{pH}, \mathrm{TA}$, and $\mathrm{CO}_{3}{ }^{2-}$ concentrations in the closed 

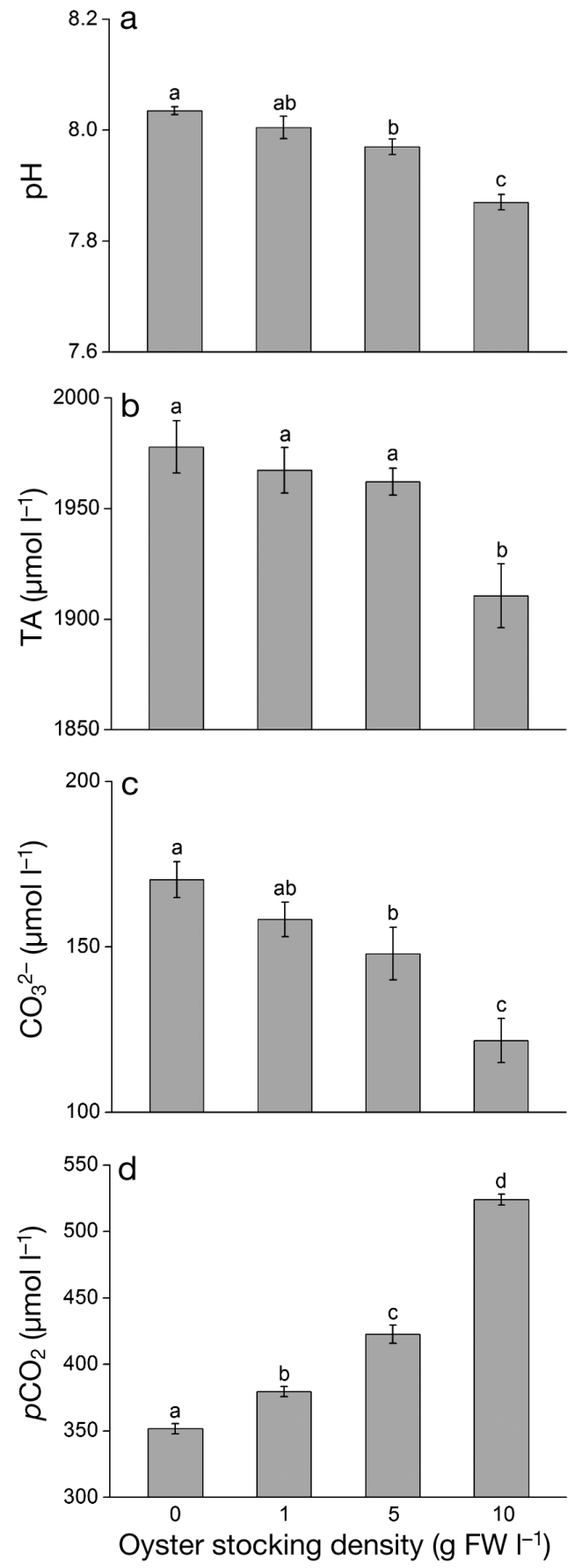

Fig. 2. Effects of Portuguese oyster Crassostrea angulata stocking density on (a) $\mathrm{pH}$, (b) total alkalinity (TA), (c) $\mathrm{CO}_{3}{ }^{2-}$, and (d) $\mathrm{pCO}_{2}$ of seawater in the closed mesocosm systems. Bars with different lowercase letters are significantly different $($ ANOVA, $p<0.05)$

mesocosms gradually decreased with increasing oyster stocking density. Values in the highest stocking density group were significantly lower than the other groups $(\mathrm{p}<0.05)$ (Fig. 2a-c). The $\mathrm{pCO}_{2}$ followed the converse general pattern, and values were signifi-
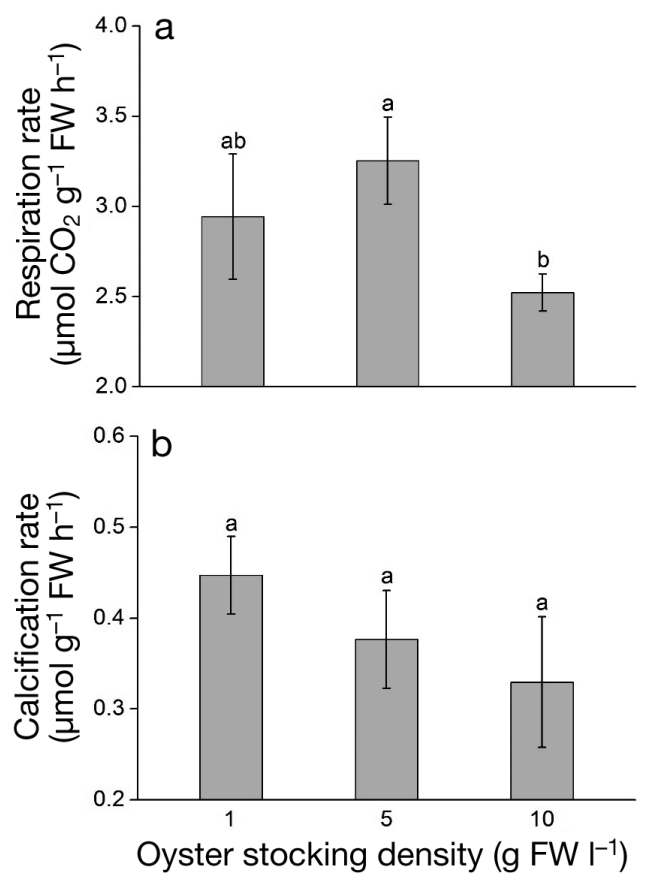

Fig. 3. (a) Respiration and (b) calcification rate of the Portuguese oyster Crassostrea angulata at different stocking densities. Bars with different lowercase letters are significantly different (ANOVA, $\mathrm{p}<0.05$ )

cantly different between each treatment $(\mathrm{p}<0.05)$ (Fig. 2d).

The lowest and highest respiration rates of oysters were found in the high- and medium-density groups, respectively, and were significantly different $(\mathrm{p}<$ 0.05) (Fig. 3a). Calcification rates of oysters decreased with increasing stocking density, but no significant difference occurred ( $p>0.05$ ) (Fig. 3b).

The total $\mathrm{CaCO}_{3}$ production by the $C$. angulata population in Daya Bay was estimated to be ca. $2150 \mathrm{~g} \mathrm{CaCO}_{3} \mathrm{~m}^{-2} \mathrm{yr}^{-1}$. C. angulata sequestered $258 \mathrm{~g} \mathrm{C} \mathrm{m}^{-2} \mathrm{yr}^{-1}$ for shell formation. The ratio of $\mathrm{CO}_{2}$ released to $\mathrm{CaCO}_{3}$ precipitated $(\Psi)$ ranged from 0.54 to 0.65 and varied monthly with water temperature variation in Daya Bay (Table 2). $\mathrm{CO}_{2}$ released due to calcification and respiration was 153 and $349 \mathrm{~g} \mathrm{C} \mathrm{m}^{-2}$ $\mathrm{yr}^{-1}$, respectively.

\section{Variations of seawater $\mathrm{pH}$ and TA in different mesocosms}

As shown in Fig. 4a, the seawater $\mathrm{pH}$ differed significantly among different mesocosms $(\mathrm{p}<0.05)$. $\mathrm{pH}$ was lowest in the oyster-only treatment, significantly lower than that of the control and the oyster-seaweed co-culture groups $(\mathrm{p}<0.05)$. $\mathrm{pH}$ gradually increased 
Table 2. Mean monthly water temperature $\left(T,{ }^{\circ} \mathrm{C}\right)$ and corresponding molar ratio $(\Psi)$ in Daya Bay

\begin{tabular}{|lcc|}
\hline Month & $T$ & $\Psi$ \\
\hline January & 18.3 & 0.65 \\
February & 18.2 & 0.65 \\
March & 18.7 & 0.64 \\
April & 22.4 & 0.61 \\
May & 24.5 & 0.59 \\
June & 29.0 & 0.56 \\
July & 31.3 & 0.54 \\
August & 29.7 & 0.55 \\
September & 29.5 & 0.55 \\
October & 28.3 & 0.56 \\
November & 27.6 & 0.57 \\
December & 19.2 & 0.64 \\
Mean \pm SD & $24.7 \pm 5.1$ & $0.59 \pm 0.04$ \\
\hline
\end{tabular}

with increasing seaweed density in co-culture treatments, and was significantly higher than that of the control $(p<0.05)$. TA was highest in the control, significantly higher than that of the other groups $(\mathrm{p}<$ 0.05) (Fig. 4b). TA values in OS_4:1 and OS_2:1 coculture groups were significantly lower than that of the other groups $(\mathrm{p}<0.05)$ (Fig. 4b).

\section{Variations of seawater DIC systems and $p \mathrm{CO}_{2}$ in different mesocosms}

After $24 \mathrm{~h}$ incubation, $\mathrm{DIC}, \mathrm{HCO}_{3}{ }^{-}$, and $\mathrm{CO}_{2}$ concentrations and $p \mathrm{CO}_{2}$ showed similar trends among treatments (Fig. 5a,b,d,e). The highest values were found in the oyster-only group, and then continuously decreased with increasing seaweed density in co-culture groups. Co-culture with seaweed lead to a significant decrease of $\mathrm{CO}_{2}$ concentration and $p \mathrm{CO}_{2}$ $(p<0.05)$. The degree of reduction was positively correlated with the seaweed density (Fig. 5d,e). $\mathrm{CO}_{3}{ }^{2-}$ concentration followed the converse general pattern to $\mathrm{HCO}_{3}{ }^{-}$concentrations (Fig. 5c).

\section{Variations of air-sea $\mathrm{CO}_{2}$ flux in different mesocosms}

The air-sea $\mathrm{CO}_{2}$ flux $\left(F_{\mathrm{CO} 2}\right)$ in the oyster-only treatment group had a high and positive value $(110.4 \pm$ $10.5 \mathrm{mmol} \mathrm{m}^{-2} \mathrm{~d}^{-1}$ ), representing a $\mathrm{CO}_{2}$ source to the atmosphere, and was significantly higher than in the other groups $(\mathrm{p}<0.05)$. In contrast, the negative values (from $-[8.4 \pm 0.7]$ to $-[33.6 \pm 4.0] \mathrm{mmol} \mathrm{m}^{-2} \mathrm{~d}^{-1}$ ) in the control and co-culture groups represent a $\mathrm{CO}_{2}$ sink from the atmosphere to the sea, where the
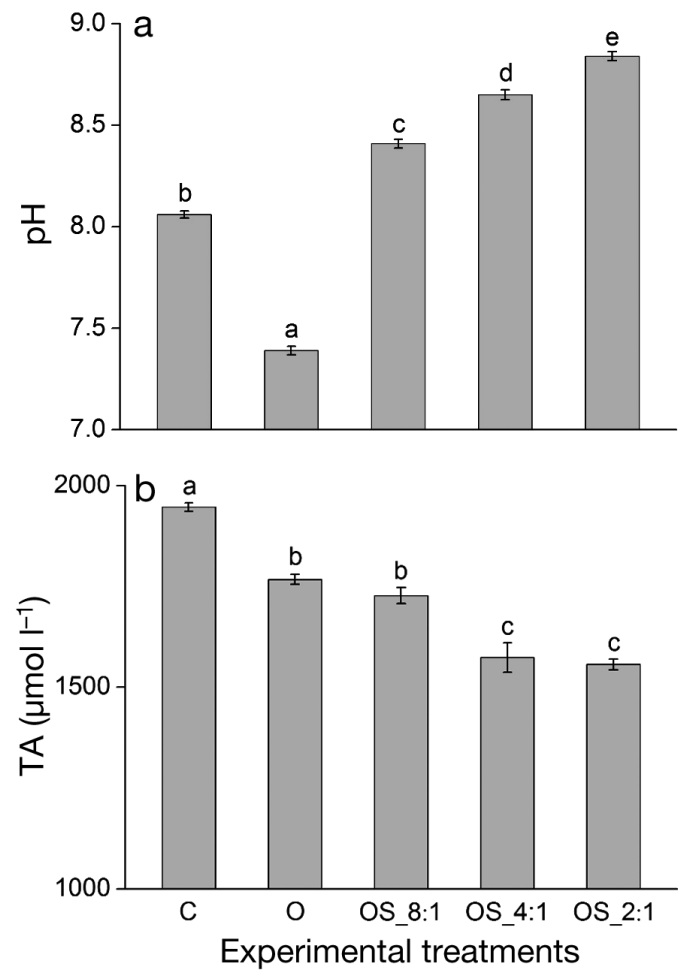

Fig. 4 (a) Seawater pH and (b) total alkalinity (TA) of oyster Crassostrea angulata monoculture and oyster-seaweed Gracilaria lemaneiformis co-culture mesocosms. C: control; O: oyster only; OS_8:1, OS_4:1, and OS_2:1: oyster cocultured with seaweed at ratios of $8: 1,4: 1$, and $2: 1$, respectively. Bars with different lowercase letters are significantly different (ANOVA, p < 0.05)

degree of $\mathrm{CO}_{2}$ sink was proportional to seaweed stocking density; there was no significant difference in $F_{\mathrm{CO} 2}$ between the oyster-seaweed (OS_8:1) coculture and the control $(\mathrm{p}<0.05)$, but the $F_{\mathrm{CO} 2}$ values in OS_4:1 and OS_2:1 groups were significantly lower than that in the control ( $p>0.05$ ) (Fig. 6).

\section{Oxygen production rate of Gracilaria lemaneiformis in co-culture mesocosms}

In oyster-seaweed co-culture mesocosms, although the DO was mainly produced by G. lemaneiformis, the phytoplankton also produced some oxygen. Therefore, the oxygen concentration in oysterseaweed co-culture mesocosms (Fig. 7) was refitted by the oxygen concentration in the control and oyster-only mesocosms. The net oxygen production rates in the low- (OS_8:1) and medium- (OS_4:1) seaweeddensity treatments were significantly $(p<0.05)$ higher than that in the high-seaweed-density group (OS_2:1). 

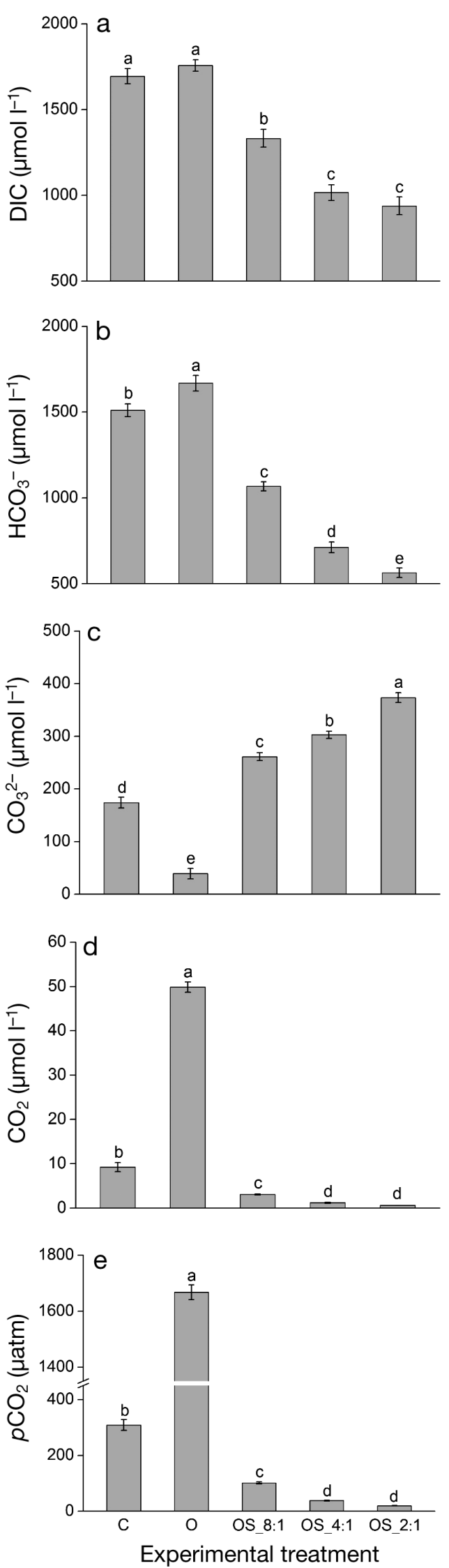

Fig. 5 Seawater concentrations of (a) dissolved inorganic carbon (DIC), (b) $\mathrm{HCO}_{3}{ }^{-}$, (c) $\mathrm{CO}_{3}{ }^{2-}$, (d) aqueous $\mathrm{CO}_{2}$, and (e) $p \mathrm{CO}_{2}$ in oyster Crassostrea angulata monocultures and oyster-seaweed Gracilaria lemaneiformis co-culture mesocosms (see Table 1 for treatments). Bars with different lowercase letters are significantly different (ANOVA, $\mathrm{p}<0.05$ )

\section{DISCUSSION}

The results of the present study indicated that the oyster Crassostrea angulata cultivated in Daya Bay seems to be a $\mathrm{CO}_{2}$ generator, as $p \mathrm{CO}_{2}$ increased in oyster-only culture mesocosms. Oyster harvesting sequesters ca. $258 \mathrm{~g} \mathrm{C} \mathrm{m}^{-2} \mathrm{yr}^{-1}$ due to shell formation in Daya Bay. In contrast, the $\mathrm{CO}_{2}$ fluxes due to respiration and calcification were ca. 349 and $153 \mathrm{~g} \mathrm{C} \mathrm{m}^{-2}$ $\mathrm{yr}^{-1}$, respectively, accounting for $69.5 \%$ and $30.5 \%$ of the total $\mathrm{CO}_{2}$ fluxes $\left(502 \mathrm{~g} \mathrm{C} \mathrm{m}^{-2} \mathrm{yr}^{-1}\right)$, respectively.

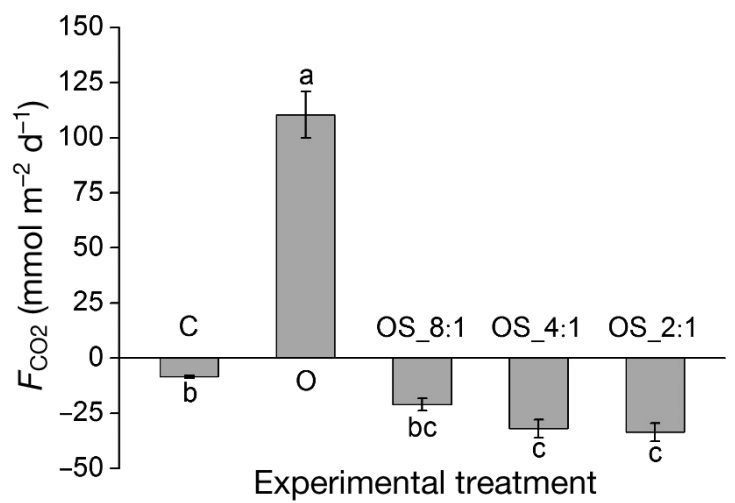

Fig. 6. Variations in air-sea $\mathrm{CO}_{2}$ flux $\left(F_{\mathrm{CO} 2}\right)$ among different experimental mesocosms. C: control; O: oyster only; OS_8:1, OS_4:1, and OS_2:1: oyster co-cultured with seaweed at ratios of $8: 1,4: 1$, and 2:1, respectively. Bars with different lowercase letters are significantly different (ANOVA, $p<0.05$ )

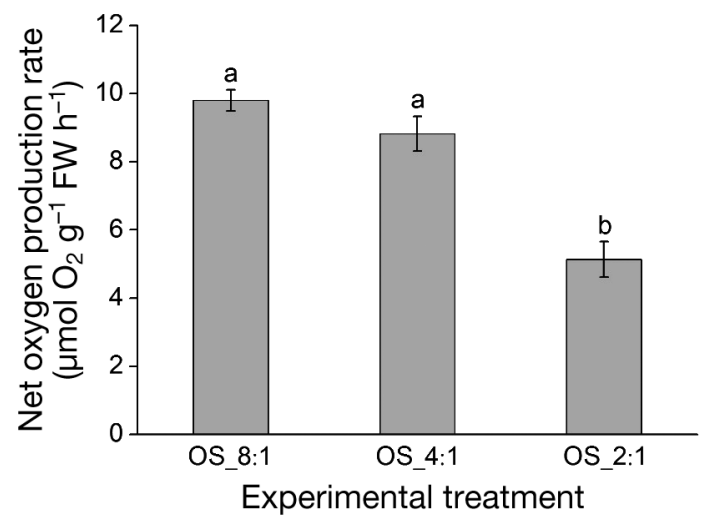

Fig. 7. Net oxygen production rates of seaweed Gracilaria lemaneiformis in oyster Crassostrea angulata-seaweed coculture mesocosms (see Table 1 for treatments). Bars with different lowercase letters are significantly different $($ ANOVA, $\mathrm{p}<0.05)$ 
This result indicated that total carbon fluxes were mainly influenced by respiration, but the contribution of calcification was not negligible. Based on the balance between $\mathrm{CaCO}_{3}$ sequestration and $\mathrm{CO}_{2}$ release, the $C$. angulata populations in Daya Bay increase $\mathrm{CO}_{2}$ release to the atmosphere in coastal ecosystems. Moreover, our measurements may have underestimated the overall contribution of $C$. angulata to $\mathrm{CO}_{2}$ fluxes, since we have not considered the rate of carbonate dissolution of shells that remained in the system after oyster death.

During the $4 \mathrm{~h}$ incubation, the DO concentrations in all mesocosms were above $4 \mathrm{mg} \mathrm{l}^{-1}$. This level was not likely to induce stress to the oysters (Diaz \& Rosenberg 2008). The reduced respiration rate by oysters in the high-density group (Fig. 3a) might be a strategy to cope with variability in seawater $\mathrm{pH}$ and the ability to adapt to seawater acidification (Guppy \& Withers 1999, Langenbuch \& Pörtner 2004).

Seawater $\mathrm{CO}_{3}{ }^{2-}$ can affect the ability of calcifying organisms to precipitate $\mathrm{CaCO}_{3}$ (Gazeau et al. 2007, Zhang et al. 2011, Dineshram et al. 2013, Li et al. 2013, Mos et al. 2015, McGrath et al. 2016). However, in the present experiment, no significant differences in calcification rate were found among the different density treatments (Fig. 3b), although the $\mathrm{CO}_{3}{ }^{2-}$ was lower in the high-density group (Fig. 2c). This might indicate that the $\mathrm{CO}_{3}{ }^{2-}$ deficiency stress was not severe enough to depress calcification. Therefore, further studies with longer incubation times and/or larger biomass of oysters are needed to produce more severe acidification stress.

According to the calcification rate and culture density of oysters, the mean $\mathrm{CaCO}_{3}$ production by $C$. angulata population in Daya Bay is ca. $2150 \mathrm{~g} \mathrm{CaCO}_{3}$ $\mathrm{m}^{-2} \mathrm{yr}^{-1}$. This is higher than that of the oyster Crassostrea gigas (134 $\mathrm{g} \mathrm{CaCO}_{3} \mathrm{~m}^{-2} \mathrm{yr}^{-1}$ ) in Brest Bay (Lejart et al. 2012). Varying results could be due to species-specific differences. Lejart et al. (2012) studied the natural populations of $C$. gigas, which inhabit the intertidal zone going through $14 \mathrm{~h}$ of underwater respiration and calcification, and $10 \mathrm{~h}$ aerial respiration each day with the changing tides. However, $C$. angulata in Daya Bay were cultured under constant immersion conditions. Therefore, C. angulata has a longer period of calcification to produce higher amounts of $\mathrm{CaCO}_{3}$.

$\mathrm{CO}_{2}$ released during $\mathrm{CaCO}_{3}$ precipitation of oysters in Daya Bay represented about $30.5 \%$ of the total $\mathrm{CO}_{2}$ production. This result was consistent with previous findings, e.g. $30 \%$ for Ophiothrix fragilis (Migné et al. 1998), 33 \% for Potamocorbula amurensis (Chauvaud et al. 2003), and 23-26\% for Acroc- nida brachiata (Davoult et al. 2009) in the eastern English Channel. Therefore, although total carbon fluxes were mainly influenced by underwater respiration, there is a contribution from calcification that should not be neglected.

Gracilaria lemaneiformis can use both $\mathrm{CO}_{2}$ and $\mathrm{HCO}_{3}{ }^{-}$for photosynthesis. In the oyster-seaweed coculture mesocosm, the $\mathrm{HCO}_{3}{ }^{-}$concentration was significantly higher in the OS_4:1 group than in the OS_2:1 group, but there was no significant difference in $\mathrm{CO}_{2}$ concentration (Fig. 5). This phenomenon was consistent with the findings of Raven et al. (2014) and Axelsson et al. (2000), who reported that in seawater of $\mathrm{pH} 8.0$ and above, the principal species of DIC in the medium is $\mathrm{HCO}_{3}{ }^{-}$, but the active transport of $\mathrm{HCO}_{3}{ }^{-}$needs higher energy than passive $\mathrm{CO}_{2}$ diffusion. Hence, it is reasonable that $G$. lemaneiformis has a higher affinity for $\mathrm{CO}_{2}$ than $\mathrm{HCO}_{3}{ }^{-}$, which lead to a preferential $\mathrm{CO}_{2}$ exhaust over $\mathrm{HCO}_{3}{ }^{-}$.

In the present study, calcification and respiration by oysters occurred over the duration of $24 \mathrm{~h}$ in the closed mesocosm system, while photosynthesis by $G$. lemaneiformis occurred only during the daytime when there is light. The $\mathrm{CO}_{2}: \mathrm{CO}_{3}{ }^{2-}$ ratio and $\mathrm{pH}$ of the seawater in the co-culture system would depend on the balance between the photosynthesis rate by the seaweed and the respiration rate and calcification rate of the oysters (Menéndez et al. 2001, Zhang et al. 2012). Seawater $p \mathrm{CO}_{2}$ and $\mathrm{CO}_{2}: \mathrm{CO}_{3}{ }^{2-}$ ratios decreased in all oyster-seaweed co-culture systems, indicating that there was stronger $\mathrm{CO}_{2}$ uptake by $G$. lemaneiformis than $\mathrm{CO}_{2}$ release from $C$. angulata, leading to a net uptake of $\mathrm{CO}_{2}$ from the atmosphere into the seawater. Meanwhile, we found that the net oxygen production rate of $G$. lemaneiformis in the OS_2:1 treatment was significantly decreased compared with that in the OS_8:1 and OS_4:1 groups (Fig. 7). As the primary production of seaweed is carbon limited, the carbon-saturated maximum photosynthesis of $G$. lemaneiformis would drastically reduce when it was 'starved' of DIC (Han et al. 2013). Since the numbers of oysters among the 3 treatments were almost the same, the decreased oxygen production rate i.e. the photosynthesis rate of G. lemaneiformis in the OS_2:1 group was probably due to a carbon limitation. Thus, there could be an evident interspecies mutual benefit for both $C$. angulata and G. lemaneiformis in the co-culture system. Based on the results of the present study, we suggest that the 2 species are co-cultured at a ratio of ca. 4:1 (fresh weight) for efficient utilization of seawater DIC by G. lemaneiformis, and further to increase the ocean $\mathrm{CO}_{2}$ sink. 
In conclusion, the physiological activities of $C$. angulata lead to a shift in the seawater DIC system equilibria towards higher $\mathrm{CO}_{2}$, lower $\mathrm{pH}$, and lower $\mathrm{CO}_{3}{ }^{2-}$ concentration, and subsequently are affected by this shift. Seaweed G. lemaneiformis could act as an efficient sink for $\mathrm{CO}_{2}$. Incorporation of seaweed into oyster aquaculture can be helpful in eliminating DIC release from $C$. angulata. There could be complex interspecies effects between $C$. angulata and $G$. lemaneiformis. The beneficial effects of an integrated multi-trophic aquaculture system on seawater carbon budget and air-sea $\mathrm{CO}_{2}$ fluxes should be determined based on an ecosystem approach.

Acknowledgements. This study was supported by Major State Basic Research Development Program of China (973 Program, 2015CB452904, 2015CB4529001), National Natural Science Foundation of China (31602183, 41106088), Special Fund of Basic Research for Central non-profit Scientific Research Institutes (2016YD02, 2014A01YY03), Guangdong Natural Science Foundation (2014A030310331), Project of Science and Technology of Guangdong Province (2016A 020222024, 2014B030301064), the Key Laboratory of South China Sea Fishery Resources Development and Utilization, Ministry of Agriculture (LSF2014-05).

\section{LITERATURE CITED}

Axelsson L, Mercado JM, Figueroa FL (2000) Utilization of $\mathrm{HCO}_{3}{ }^{-}$at high $\mathrm{pH}$ by the brown macroalga Laminaria saccharina. Eur J Phycol 35:53-59

* Chauvaud L, Thompson JK, Cloern JE, Thouzeau G (2003) Clams as $\mathrm{CO}_{2}$ generators: the Potamocorbula amurensis example in San Francisco Bay. Limnol Oceanogr 48: 2086-2092

China Bureau of Fisheries (2016) China Fisheries Yearbook in 2016. Agricultural Press of China, Beijing

Davoult D, Harlay J, Gentil F (2009) Contribution of a dense population of the brittle star Acrocnida brachiata (Montagu) to the biogeochemical fluxes of $\mathrm{CO}_{2}$ in a temperate coastal ecosystem. Estuaries Coasts 32:1103-1110

* Diaz RJ, Rosenberg R (2008) Spreading dead zones and consequences for marine ecosystems. Science 321:926-929

Dickson AG (1990) Standard potential of the reaction: $\mathrm{AgCl}(\mathrm{s})+1 / 2 \mathrm{H}_{2}(\mathrm{~g})=\mathrm{Ag}(\mathrm{s})+\mathrm{HCl}(\mathrm{aq})$, and the standard acidity constant of the ion $\mathrm{HSO}_{4}{ }^{-}$in synthetic seawater from 273.15 to $318.15 \mathrm{~K}$. J Chem Thermodyn 22:113-127

Dickson AG (2010) The carbon dioxide system in seawater: equilibrium chemistry and measurements. In: Riebesell U, Fabry VJ, Hansson L, Gattuso JP (eds) Guide to best practices for ocean acidification research and data reporting. Publications Office of the European Union, Luxembourg, p 17-52

Dickson AG, Millero FJ (1987) A comparison of the equilibrium constants for the dissociation of carbonic acid in seawater media. Deep-Sea Res 34:1733-1743

Nineshram R, Thiyagarajan V, Lane A, Yu ZN, Shu X, Leung PTY (2013) Elevated $\mathrm{CO}_{2}$ alters larval proteome and its phosphorylation status in the commercial oyster, Crassostrea hongkongensis. Mar Biol 160:2189-2205
Fang JG, Zhang J, Xiao T, Huang DJ, Liu SM (2016) Integrated multi-trophic aquaculture (IMTA) in Sanggou Bay, China. Aquacult Environ Interact 8:201-205

Faraway JJ (2002) Practical regression and ANOVA using R. http://cran.r-project.org/doc/contrib/Faraway-PRA.pdf (accessed on 20 January 2014)

Frankignoulle M, Canon C, Gattuso JP (1994) Marine calcification as a source of carbon dioxide: positive feedback of increasing atmospheric $\mathrm{CO}_{2}$. Limnol Oceanog 39:458-462

Frankignoulle M, Pichon M, Gattuso JP (1995) Aquatic calcification as a source of carbon dioxide. In: Beran MA (ed) Carbon sequestration in the biosphere. NATO ASI Series (Series I: Global Environmental Change) Vol 33. Springer, Berlin, p 265-271

* Gazeau F, Quiblier C, Jansen JM, Gattuso J, Middelburg JJ, Heip CHR (2007) Impact of elevated $\mathrm{CO}_{2}$ on shellfish calcification. Geophys Res Lett 34:L07603

Goulletquer P, Wolowicz M (1989) The shell of Cardium edule, Cardium glaucum and Ruditapes philippinarum: organic content, composition and energy value, as determined by different methods. J Mar Biol Assoc UK 69: $563-572$

Guppy M, Withers P (1999) Metabolic depression in animals: physiological perspectives and biochemical generalizations. Biol Rev Camb Philos Soc 74:1-40

*Han TT, Jiang ZJ, Fang JG, Zhang JH and others (2013) Carbon dioxide fixation by the seaweed Gracilaria lemaneiformis in integrated multi-trophic aquaculture with the scallop Chlamys farreri in Sanggou Bay, China. Aquacult Int 21:1035-1043

Ho M, Carpenter RC (2017) Differential growth responses to water flow and reduced $\mathrm{pH}$ in tropical marine macrolagae. J Exp Mar Biol Ecol 491:58-65

Jiang ZJ, Fang JG, Han TT, Mao YZ, Li JQ, Du MR (2014) The role of Gracilaria lemaneiformis in eliminating the dissolved inorganic carbon released from calcification and respiration process of Chlamys farreri. J Appl Phycol 26:545-550

炎Langenbuch M, Pörtner HO (2004) High sensitivity to chronically elevated $\mathrm{CO}_{2}$ levels in a eurybathic marine sipunculid. Aquat Toxicol 70:55-61

Lejart M, Clavier J, Chauvaud L, Hily C (2012) Respiration and calcification of Crassostrea gigas: contribution of an intertidal invasive species to coastal ecosystem $\mathrm{CO}_{2}$ fluxes. Estuaries Coasts 35:622-632

* Lerman A, Mackenzie FT (2005) $\mathrm{CO}_{2}$ air-sea exchange due to calcium carbonate and organic matter storage, and its implications for the global carbon cycle. Aquat Geochem 11:345-390

ㄴ. J, Jiang Z, Zhang J, Qiu JW, Du M, Bian D, Fang J (2013) Detrimental effects of reduced seawater $\mathrm{pH}$ on the early development of the Pacific abalone. Mar Pollut Bull 74: 320-324

* Mackenzie FT, Andersson AJ (2013) The marine carbon system and ocean acidification during Phanerozoic time. Geochem Perspect 2:1-3

*Martin S, Thouzeau G, Chauvaud L, Jean F, Guerin L, Clavier J (2006) Respiration, calcification, and excretion of the invasive slipper limpet, Crepidula fornicata L.: implications for carbon, carbonate, and nitrogen fluxes in affected areas. Limnol Oceanogr 51:1996-2007

* McGrath T, McGovern E, Cave RR, Kivimäe C (2016) The inorganic carbon chemistry in coastal and shelf waters around Ireland. Estuaries Coasts 39:27-39 
Mehrbach C, Culberson CH, Hawley JE, Pytkowicz RM (1973) Measurement of the apparent dissociation constants of carbonic acid in seawater at atmospheric pressure. Limnol Oceanogr 18:897-907

Menéndez M, Martínez M, Comín FA (2001) A comparative study of the effect of $\mathrm{pH}$ and inorganic carbon resources on the photosynthesis of three floating macroalgae species of a Mediterranean coastal lagoon. J Exp Mar Biol Ecol 256:123-136

Migné A, Davoult D, Gattuso JP (1998) Calcium carbonate production of a dense population of the brittle star Ophiothrix fragilis (Echinodermata: Ophiuroidea): role in the carbon cycle of a temperate coastal ecosystem. Mar Ecol Prog Ser 173:305-308

Millero FJ (1995) Thermodynamics of the carbon dioxide system in the oceans. Geochim Cosmochim Acta 59: 661-677

Mistri M, Munari C (2013) The invasive bag mussel Arcuatula senhousia is a $\mathrm{CO}_{2}$ generator in near-shore coastal ecosystems. J Exp Mar Biol Ecol 440:164-168

Mos B, Byrne M, Cowden KL, Dworjanyn SA (2015) Biogenic acidification drives density-dependent growth of a calcifying invertebrate in culture. Mar Biol 162: 1541-1558

Munari C, Rossetti E, Mistri M (2013) Shell formation in cultivated bivalves cannot be part of carbon trading systems: a study case with Mytilus galloprovincialis. Mar Environ Res 92:264-267

Peters RH (1983) The ecological implications of body size. Cambridge University Press, New York, NY

Pierrot D, Lewis E, Wallace DWR (2006) MS Excel program developed for $\mathrm{CO}_{2}$ system calculations. ORNL/CDIAC$105[\mathrm{R}]$. Carbon dioxide Information Analysis Center, Oak Ridge National Laboratory, US Department of Energy, Oak Ridge, TN

Raven JA, Beardall J, Giordano M (2014) Energy costs of carbon dioxide concentrating mechanisms in aquatic organisms. Photosynth Res 121:111-124

Rumohr H, Brey T, Ahkar S (1987) A compilation of biometric conversion factors for benthic invertebrates of the Baltic Sea. The Baltic Marine Biologists Publications Vol 9

Editorial responsibility: Symon Dworjanyn, Coffs Harbour, New South Wales, Australia
Scanes E, Parker LM, O'Connor WA, Stapp LS, Ross PM (2017) Intertidal oysters reach their physiological limit in a future high- $\mathrm{CO}_{2}$ world. J Exp Biol 220:765-774

* Schwinghamer P, Hargrave B, Peer D, Hawkins CM (1986) Partitioning of production and respiration among size groups of organisms in an intertidal benthic community. Mar Ecol Prog Ser 31:131-142

Strickland JD, Parson TR (1972) A practical handbook of seawater analysis, Vol 167, 2nd edn. Bulletin of the Fish Research Board of Canada, Ottawa, p 310

Takahashi T, Sutherland SC, Sweeney C, Poisson A and others (2002) Global sea-air $\mathrm{CO}_{2}$ flux based on climatological surface ocean $p \mathrm{CO}_{2}$, and seasonal biological and temperature effects. Deep Sea Res II 49:1601-1622

Uppstrom LR (1974) The boron/chloronity ratio of deep-sea water from the Pacific Ocean. Deep-Sea Res 21:161-162

*Veron JEN (2011) Ocean acidification and coral reefs: an emerging big picture. Diversity 3:262-274

*Wanninkhof R (1992) Relationship between wind speed and gas exchange over the ocean. J Geophys Res 97: 7373-7382

*Wanninkhof R, McGillis WM (1999) A cubic relationship between gas transfer and wind speed. Geophys Res Lett 26:1889-1892

Weiss RF (1974) Carbon dioxide in water and seawater: the solubility of a non-ideal gas. Mar Chem 2:203-215

Yu ZH, Jiang T, Xia JJ, Ma YE, Zhang T (2014) Ecosystem service value assessment for an oyster farm in Dapeng Cove. Shuichan Xuebao 38:853-860 (in Chinese with English abstract)

Zhang ML, Fang JG, Zhang JH, Li B, Ren SM, Mao YZ, Gao YP (2011) Effect of marine acidification on calcification and respiration of Chlamys farreri. J Shellfish Res 30: 267-271

* Zhang N, Song J, Cao C, Ren R, Wu F, Zhang S, Sun X (2012) The influence of macronitrogen $\left(\mathrm{NO}_{3}{ }^{-}\right.$and $\left.\mathrm{NH}_{4}{ }^{+}\right)$ addition with Ulva pertusa on dissolved inorganic carbon system. Acta Oceanol Sin 31:73-82

Z Zou DH, Xia JR, Yang YF (2004) Photosynthetic use of exogenous inorganic carbon in the agarophyte Gracilaria lemaneiformis (Rhodophyta). Aquaculture 237:421-431

Submitted: May 29, 2017; Accepted: October 4, 2017 Proofs received from author(s): November 22, 2017 